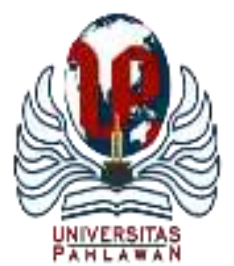

\title{
JURNALBASICEDU
}

Volume 6 Nomor 1 Tahun 2022 Halaman 253 - 261

Research \& Learningin Elementary Education

https://jbasic.org/index.php/basicedu

\section{Implementasi Pendekatan Science, Enviroment, Technology, and Society (SETS) terhadap Kemampuan Berpikir Kritis Peserta Didik Sekolah Dasar}

\section{Frida Destini $^{1 凶}{ }^{\bowtie}$, Di Yulianti ${ }^{2}$, Lilik Sabdaningtyas ${ }^{3}$, Alben Ambarita ${ }^{4}$, Rochmiyati $^{5}$}

Pendidikan Guru Sekolah Dasar, Universitas Lampung, Indonesia ${ }^{1,2,3,4,5}$

E-mail: frida.destini@fkip.unila.ac.id ${ }^{1}$, safira shodiq@yahoo.com ${ }^{2}$, lilik.sabdaningtyas@ fkip.unila.ac.id ${ }^{3}$, alben.ambarita@fkip.unila.ac.id ${ }^{4}, \underline{\text { rochmiyatiazwardi@yahoo.co.id }}^{5}$

\begin{abstract}
Abstrak
Masalah dalam penelitian ini adalah rendahnya kemampuan berpikir kritis peserta didik. Penelitian ini bertujuan untuk mengetahui pengaruh implementasi pendekatan SETS terhadap kemampuan berpikir kritis peserta didik. Desain penelitian yang digunakan yaitu non-equivalent control group design.Subjek penelitian berjumlah 59 peserta didik. Teknik pengumpulan data adalah teknik tes dan nontes. Teknik tes dalam penelitian ini digunakan untuk mengukur kemampuan berpikir kritis peserta didik. Teknik non-tes berupa angket, observasi, wawancara, dan dokumentasi. Teknik analisis data menggunakan uji regresi sederhana untuk mengetahui pengaruh X (pendekatan SETS) terhadap Y (kemampuan berpikir kritis) dan uji independent sampel t-test untuk mengetahui perbedaan antara peserta didik yang belajar menggunakan pendekatan SETS dengan peserta diik yang belajar menggunakan pendekatan saintifik. Hasil penelitian menunjukan bahwa terdapat pengaruh penerapan pendekatan SETS terhadap kemampuan berpikir kritis peserta didik dengan $F_{\text {hitung }}>F_{\text {tabel }}$ yaitu 34,12 >4,18 $(\alpha=0,05)$, serta terdapat perbedaan hasil belajar pada kelas eksperimen sebesar 0,53 bertaraf sedang dan peningkatan pada kelas kontrol sebesar 0,42 bertaraf sedang. Hal itu berarti terdapat perbedaan antara peserta didik yang belajar menggunakan pendekatan SETS dengan peserta didik yang belajar menggunakan pendekatan saintifik.
\end{abstract}

Kata Kunci: Science, Environment, Technology, and Society (SETS), Berpikir Kritis, Sekolah Dasar.

\begin{abstract}
The problem in this research is the low critical thinking ability of students. This study aims to determine the effect of implementing the SETS approach on students' critical thinking skills. The research design used was non-equivalent control group design. The research subjects were 59 students. Data collection techniques are test and non-test techniques. The test technique in this study was used to measure students' critical thinking skills. Non-test techniques in the form of questionnaires, observations, interviews, and documentation. The data analysis technique used a simple regression test to determine the effect of $X$ (SETS approach) on $Y$ (critical thinking ability) and independent sample t-test to determine the difference between students who learn to use the SETS approach and students who learn to use the scientific approach. The results showed that there was an effect of applying the SETS approach to students' critical

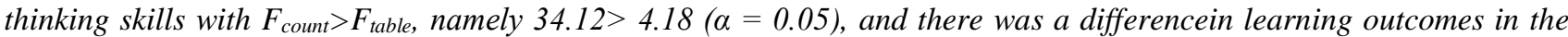
experimental class of 0.534 with a moderate level and an increase in learning outcomes in the experimental class. in the control class of 0.42 medium level. This means that there are differences between students who learn to use the SETS approach and students who learn to use a scientific approach.
\end{abstract}

Keywords: Science, Environment, Technology, and Society (SETS), Critical Thinking, Elementary School

Copyright (c) 2022 Frida Destini, Dwi Yulianti, Lilik Sabdaningtyas, Alben Ambarita, Rochmiyati

$\checkmark$ Corresponding author :

Email : frida.destini@fkip.unila.ac.id

DOI : https://doi.org/10.31004/basicedu.v6i1.1615 


\section{PENDAHULUAN}

Era millennium pada abadke-21 ini ditandai dengan perkembangan sains dan teknologi yang sangat berkembang dengan pesat. Semua bangsa di dunia termasuk Bangsa Indonesia sangat bergantung pada penggunaan sains dan teknologi secara bijaksana. Keterampilan abad 21 dapat memperkuat modal sosial (social capital)dan modal intelektual (intellectual capital) dengan karakteristik keterampilan 4C,yaitu communication, collaboration, critical thinking and problem solving sertacreativity and inovation. Hal ini menuntut peserta didik untuk dapat menguasai berbagai keterampilan guna menghadapi abad 21 sehingga dapat bersaing di era global. Upaya pemerintah untuk memperbaiki sistem pendidikan ialah dengan cara memberlakukan kurikulum 2013. Penerapan kurikulum 2013 sebagai upaya menyelaraskan pendidikan sesuai dengan perkembangan zaman, tuntutan kemajuan sains dan teknologi serta kebutuhan dalam kehidupan. Kurikulum 2013 mengacu pada kemampuan yang diperlukan diabad 21. Kurikulum 2013 merupakan kurikulum terpadu sebagai pendekatan pembelajaran yang melibatkan beberapa disiplin ilmu untuk memberikan pengalaman yang bermakna dan luas kepada peserta didik.

Berdasarkan hasil observasi di SDN 05 Metro Pusat, bahwa SDN 05 Metro Pusat sudah menerapkan Kurikulum 2013. Akan tetapi pada proses pembelajaran tematik, pendidik belum maksimal dalam penguasaan materi pembelajaran tematik bagi peserta didik, pendidik tidak memfasilitasi peserta didik untuk mengembangkan kemampuan berpikir kritis. Pendidik juga belum menerapkan pendekatan pembelajaran yang mengaitkan pada lingkungan, sains dan teknologi, serta masyarakat sehingga peserta didik belum mampu menentukan tindakan memecahkan masalah dengan kemampuan berpikir kritis. Kemampuan berpikir kritis merupakan kemampuan berpikir yang sangat penting diperlukan dalam kehidupan. Setiap manusia memiliki potensi untuk menjadi kritis serta dapat lebih baik jika kemampuan tersebut dilibatkan secara formal maupun informal. Berpikir kritis ialah kemampuan berpikir dengan cara memeriksa, menghubungkan, dan mengevaluasi semua aspek dari suatu masalah. Sifat dari kemampuan berpikir ini adalah analitis dan refleksif. Kemampuan berpikir kritis dapat dikembangkan melalui pembelajaran tematik.

Pembelajaran tematik ialah jenis pembelajaran yang memberikan banyak perhatian pada pengembangan peserta didik dengan memberikan konsep yang didasarkan pada tingkat perkembangan peserta didik. Kemampuan berpikir kritis peserta didik tidak muncul dengan sendirinya pada diri peserta didik. Tetapi perlu adanya pendekatan pembelajaran, baik metode maupun sumber belajar yang digunakan untuk meningkatkan kemampuan berpikir kritis peserta didik. Menurut (Kusumah, 2019) berpikir kritis itu meliputi dua langkah besar yakni melakukan proses berpikir nalar (reasoning) dan diikuti dengan pengambilan keputusan/pemecahan masalah (deciding/problem solving). Dengan demikian dapat diartikan bahwa tanpa kemampuan yang memadai dalam hal berpikir nalar, sesorang tidak dapat melakukan proses berpikir kritis secara benar. Pendapat tersebut juga sejalan dengan pernyataan yang disampaikan (Ristiasari et al., 2012) kemampuan berpikir kritis merupakan kompetensi yang harus dimiliki peserta didik. Berdasarkan informasi permasalahan diatas maka untuk meningkatkan kemampuan berpikir kritis peserta didik pada pembelajaran tematik ialah dengan menerapkan pendekatan pembelajaran yang lebih kreatif dan inovatif.

Saat ini pendekatan yang umum digunakan pada proses pembelajaran adalah pendekatan saintifik. Sudarwan dalam (Azhar, 2013) menjelaskan bahwa Kurikulum 2013 itu menekankan penerapan pendekatan saintifik dalam proses pembelajaran yang meliputi langkah-langkah kegiatan: mengamati, menanya, mencoba, mengolah, menyajikan, menyimpulkan, dan mencipta untuk semua mata pelajaran. Sejalan dengan itu pendapat lain yang menyatakan Pendekatan saintifik merupakan pendekatan yang mengadopsi langkahlangkah saintis dalam membangun pengetahuan melalui metode ilmiah. Pendekatan saintifik memungkinkan terbudayakannya kecakapan berpikir sains, terkembangkannya "sense of inquiry" dan keterampilan berpikir kritis menurut Alfred De Vito dalam (Pratiwi, 2014). Oleh karena itu peneliti menarik 
Implementasi Pendekatan Science, Enviroment, Technology, and Society (SETS) terhadap Kemampuan Berpikir Kritis Peserta Didik Sekolah Dasar - Frida Destini, Dwi Yulianti, Lilik Sabdaningtyas, Alben Ambarita, Rochmiyati

DOI: https://doi.org/10.31004/basicedu.v6i1.1615

kesimpulan bahwa pendekatan saintifik adalah model pembelajaran yang menggunakan metode ilmiah dalam kegiatan pembelajarannya. Peserta didik diberikan ruang untuk bereksplorasi terhadap materi pembelajaran, termasuk dalam kegiatan mengamati, menanya, mengumpulkan data, serta mengomunikasikan. Namun, pada kenyataannya dengan menggunakan pendekatan saintifik kemampuan berpikir kritis peserta didik dilihat dari hasil belajarnya masih tergolong rendah. Hal tersebut dapat disebabkan oleh kurangnya kemampuan pendidik untuk menyesuaikan penggunaan pendekatan pembelajaran pada saat kegiatan belajar mengajar berlangsung.

Pemaparan teori membuat peserta didik hanya memahami dari ruang lingkup pengetahuannya saja, sehingga peserta didik akan cenderung menghafal materi yang telah diajarkan oleh guru. Pembelajaran seperti itu membuat peserta didik tidak dapat mengembangkan pengetahuan yang dimilikinya dan juga peserta didik juga tidak mampu berpikir secara kritis untuk memecahkan permasalahan yang ada di lingkungan sekitarnya (Amanda et al., 2018).

Salah satu pendekatan yang dapat diterapkan ialah dengan menggunakan pendekatan Science, Environment, Technology, and Society (SETS). Kata SETS menurut (Khasanah, 2015) dimaknai sebagai sains, lingkungan, teknologi, dan masyarakat yang merupakan satu kesatuan dalam konsep pendidikan dan mempunyai implementasi supaya anak didik memiliki kemampuan berpikir tingkat tinggi (higher oder thinking). (Retno \& Marlina, 2018) berpendapat bahwa pendekatan SETS berupaya memberikan pemahaman tentang peranan lingkungan terhadap sains, teknologi, masyarakat. Termasuk juga peranan teknologi dalam penyesuaiannya dengan sains, manfaatnya terhadap masyarakat dan dampak-dampak yang ditimbulkan terhadap lingkungan. Berdasarkan hal tersebut, peneliti menyimpulkan bahwa dengan menggunakan pendekatan SETS dapat meningkatkan kemampuan berpikir kritis peserta didik, penalaran logis, penggunaan pertanyaan, dan merupakan pendekatan yang lebih kreatif untuk pemecahan masalah. Selain itu juga hasil penelitian yang dilakukan (Kusmianty et al., 2020) mengemukakan bahwa pendekatan SETS cukup efektif diterapkan dalam pembelajaran dan terdapat peningkatan terhadap kemampuan berpikir kritis. Sejalan dengan hal tersebut (Wijaya et al., 2018) mengungkapkan pendekatan SETS berpengaruh terhadap keterampilan berpikir kritis siswa. Sejalan dengan hal tersebut (Afriawan et al., 2012) berpendapat bahwa melalui pendekatan SETS diharapkan peserta didik memahami implikasi hubungan antara elemen SETS. Adapun elemen-elemen SETS adalah Science (ilmu alam), Environment ( lingkungan sekitar), dan Society (masyarakat)

Pendekatan SETS berguna untuk membimbing peserta didik supaya mampu berpikir secara menyeluruh dan utuh serta dapat memecahkan masalah lingkungan yang berkaitan dengan masyarakat dan berperan serta dalam memecahkan masalah sesuai dengan kapasitasnya.Hakekat pembelajaran dengan SETS yaitu pembelajaran harus mampu membuat peserta didik yang diminta untuk melakukan percobaan yang bersifat inquiry, kegiatan ini mengandung undur sains karena peserta didik dilatih untuk melakukan percobaan sehingga peserta didik mendapatkan data untuk dianalisis dari hasil percobaan tersebut (Ragil \& Sukiswo, 2011). Apabila pendekatan SETS digunakan secara terorganisir dan dinamis pada kegiatan pembelajaran, maka perubahan terhadap kemampuan berpikir kritis yang lebih meningkat akan terjadi (Menurut Aikenhead yang dikutip oleh (Vieira \& Tenreiro-Vieira, 2016). Berdasarkan hasil penelitian-penelitian terdahulu dapat disimpulkan bahwa pendekatan SETS dapat meningkatkan literasi ilmiah yang berhubungan dengan berpikir kritis. Adapun tujuan penelitian ini yaitu untuk mengembangkan kemampuan berpikir kritis peserta didik serta dampak penggunaannya dalam pembelajaran tematik dengan mengaitkan materi antara sains dengan lingkungan, teknologi, dan masyarakat. Oleh karena itu, peneliti berminat untuk meneliti tentang "Implementasi Science, Environment, Technology, and Society terhadap Kemampuan Berpikir Kritis Peserta Didik Sekolah Dasar". 
Implementasi Pendekatan Science, Enviroment, Technology, and Society (SETS) terhadap Kemampuan Berpikir Kritis Peserta Didik Sekolah Dasar - Frida Destini, Dwi Yulianti, Lilik Sabdaningtyas, Alben Ambarita, Rochmiyati

DOI: https://doi.org/10.31004/basicedu.v6i1.1615

\section{METODE}

Penelitian ini adalah penelitian eksperimen dengan desain penelitian yang digunakan yaitu non equivalent control group design. Lokasi penelitian dilakukan di SDN 05 Metro Pusat Kota Metro. Adapun yang menjadi populasi dalam penelitian ini adalah seluruh peserta didik kelas V SDN 05 Metro Pusat yang terdiri dari 2 kelas yaitu kelas V A yang berjumlah 31 peserta didik sebagai kelas eksperimen dan V B berjumlah 28 peserta didik sebagai kelas kontrol, sehingga jumlah populasi adalah 59 peserta didik.

Teknik pengumpulan data yang digunakan dalam penelitian ini adalah teknik tes dan non tes. Teknik tes berupa soal pilihan jamak berjumlah 20 butir soal yang akan diberikan pada saat pretest dan posttest. Teknik tes dalam penelitian ini digunakan untuk mengukur kemampuan berpikir kritis peserta didik. Sedangkan teknik nontes yang digunakan berupa angket, observasi dan dokumentasi. Langkah-langkah pelaksanaan pendekatan SETS yang digunakan dalam penelitian ini menurut National Science Teachers Association adalah (1) Tahap Invitasi, (2) Tahap Eksplorasi, (3) Tahap Solusi, (4) Tahap Aplikasi (Rini, 2017). Sedangkan pada pembelajaran saintifik tahapan-tahapan yang akan dilaksanakan adalah (1) mengamati, (2) menanyai, (3) mengumpulkan data, (4) menalar, (5) mengkomunikasikan (Machin, 2014).

Teknik analisis data dalam penelitian ini menggunakan uji regresi sederhana untuk mengetahui pengaruh variabel X (pendekatan SETS) terhadap variabel Y (kemampuan berpikir kritis) dan uji independent sampel t-test untuk mengetahui perbedaan antara peserta didik yang belajar menggunakan pendekatan SETS dengan peserta didik yang belajar menggunkan pendekatan Saintifik. Perbedaan peningkatan pengetahuan antara kelas eksperimen dengan kelas kontrol dapat dilihat pada tabel klasifikasi N-Gain berikut.

Tabel.1 Klasifikasi N-Gain

\begin{tabular}{l|l|l}
\hline No & Nilai Gain $(\mathrm{G})$ & Keterangan \\
\hline 1 & $>0,7$ & Tinggi \\
\hline 2 & $0,3-0,7$ & Sedang \\
\hline 3 & $<0,3$ & Rendah \\
\multicolumn{2}{l}{ (Sumber: } & Meltzer dalam (Khasanah, 2015)
\end{tabular}

\section{HASIL DAN PEMBAHASAN}

Kemampuan berpikir kritis merupakan kemampuan berpikir yang sangat penting diperlukan dalam kehidupan. Kemampuan berpikir kritis tidak dapat berkembang seiring dengan perkembangan jasmani tiap individu. Kemampuan ini berkaitan dengan kemampuan mengidentifikasi, menganalisis, dan memecahkan masalah secara kreatif dan berpikir logis sehingga menghasilkan pertimbangan dan keputusan yang tepat Tinio dalam (Fakhriyah, 2014). Dalam penelitian ini untuk mengetahui tingkat berpikir kritis peserta didik dengan menggunkan pendekatan SETS digunakan instrumen tes dan non tes. Menurut (Isti Nur Hayanah, 2014) secara umum dapat dikatakan bahwa SETS memiliki makna pengajaran sains yang dikaitkan dengan unsure lain dalam SETS, yakni lingkungan, teknologi, dan masyarakat.

Instrumen tes yang digunakan yaitu soal pilihan jamak berjumlah 20 butir soal yang dibagikan kepada peserta didik kelas eksperimen maupun kelas kontrol.

a. Data Hasil Pretest dan Posttest Kelas Eksperimen

Kelas eksperimen yang digunakan dalam penelitian ini adalah kelas VA. Penelitian ini bertujuan untuk mengetahui perkembangan pengetahuanpeserta didik setelah diterapkannya pendekatan Sciens, Environment, Technology, and Society (SETS) pada kelas eksperimen. 
Implementasi Pendekatan Science, Enviroment, Technology, and Society (SETS) terhadap Kemampuan Berpikir Kritis Peserta Didik Sekolah Dasar - Frida Destini, Dwi Yulianti, Lilik Sabdaningtyas, Alben Ambarita, Rochmiyati

DOI: https://doi.org/10.31004/basicedu.v6i1.1615

\section{Pretest}

Pretest bertujuan untuk mengetahui kemampuan awal yang dimiliki peserta didik. Berdasarkan hasil analisis data diketahui jumlah nilai pretest adalah 1800 . Nilai rata-rata pretest sebesar 58,6 dengan nilai tertinggi adalah 75 dan nilai terendah adalah 40 .

\section{Posttest}

Peserta didik melaksanakan soal posttest selama 25 menit setelah dilaksanakannya pembelajaran dengan menggunakan pendekatan Sciens, Environment, Technology, and Society (SETS). Hasil posttest pada kelas eksperimen dapat diketahui jumlah nilai adalah 2295. Nilai rata-rata posttest sebesar 74,03 dengan nilai tertinggi adalah 90 dan nilai terendah adalah 55 .

b. Data Hasil Pretest dan Posttest Kelas Kontrol

Kelas kontrol yang menjadi sampel dalam penelitian ini adalah kelas VB. Langkah-langkah pembelajaran yang dilakukan pendidik dengan menggunakan medote Saintifik.

\section{1) Pretest}

Hasil pretest pada kelas kontrol dapat diketahui jumlah nilai adalah 1585. Nilai rata-rata pretest sebesar 51,13 dengan nilai tertinggi adalah 75 dan nilai terendah adalah 30

\section{2) Posttest}

Hasil posttest pada kelas kontrol dapat diketahui jumlah nilai adalah 1620. Nilai rata-rata posttest sebesar 60,15 dengan nilai tertinggi adalah 90 dan nilai terendah adalah 55 .

Tabel 2. Deskripsi data hasil penelitian

\begin{tabular}{ccccc}
\hline \multirow{2}{*}{ Data } & \multicolumn{2}{c}{ Kelas Eksperimen } & \multicolumn{2}{c}{ Kelas Kontrol } \\
\cline { 2 - 5 } & Pretest & Posttest & Pretest & Posttest \\
\hline $\mathrm{N}$ & 31 & 31 & 28 & 28 \\
\hline$\Sigma$ & 1800 & 2295 & 1620 & 1985 \\
\hline X Tertinggi & 75 & 90 & 75 & 90 \\
\hline X Terendah & 40 & 55 & 40 & 55 \\
\hline Mean & 58,28 & 74,03 & 49,09 & 60,15 \\
\hline Standar Deviasi & 8.164 & 8.790 & 8.870 & 9.327 \\
\hline
\end{tabular}

Berdasarkan tabel tersebut dapat diketahui bahwa nilai mean atau rata-rata pretest pada kelas kontrol adalah 49,09, nilai mean atau rata-rata posttest kelas kontrol sebesar 60,15. Mean pretest pada kelas eksperimen adalah sebesar 58,28, nilai mean posttest kelas eksperimen sebesar 74,05.

c. Rata-rata Hasil Pretest dan Posttest

Kelas eksperimen dan kelas kontrol diberikan pretest dan posttest dari butir soalyang telah diuji validitas dan reliabilitasnya. Analisis data hasil pretest dan posttest peserta didik diperoleh nilai rata-rata pretest dan posttest pada kelas eksperimen dan kelas kontrol. Berikut nilai pretest dan posttest peserta didik dari kedua kelas.

Tabel 3. Nilai pretest dan posttest peserta didik kelas

\begin{tabular}{llclllll}
\hline \multirow{2}{*}{ No } & $\begin{array}{l}\text { Data } \\
\text { Penelitian }\end{array}$ & \multicolumn{2}{c}{ Rata-rata } & \multicolumn{2}{c}{ NilaiTertinggi } & \multicolumn{2}{l}{ NilaiTerendah } \\
\cline { 3 - 7 } & & Pretest & Posttest & Pretest & Posttest & Pretest & Posttest \\
\hline 1 & Eksperimen & 58,06 & 74,03 & 75 & 90 & 40 & 55 \\
\hline 2 & Kontrol & 49,09 & 60,15 & 75 & 90 & 40 & 55 \\
\hline
\end{tabular}



Kemampuan Berpikir Kritis Peserta Didik Sekolah Dasar - Frida Destini, Dwi Yulianti, Lilik Sabdaningtyas, Alben Ambarita, Rochmiyati

DOI: https://doi.org/10.31004/basicedu.v6i1.1615

Terdapat perbedaan nilai rata-rata antara kelas eksperimen dengankelas kontrol, dikarenakan kelas eksperimen menerapkan pendekatan Science, Environment, Technology, andSociety (SETS) sedangkan kelas kontrol menggunakan pendekatan saintifik. Perbandingan nilai rata-rata kelas eksperimen dan kelas kontrol dapat digambarkan dalam diagram berikut.

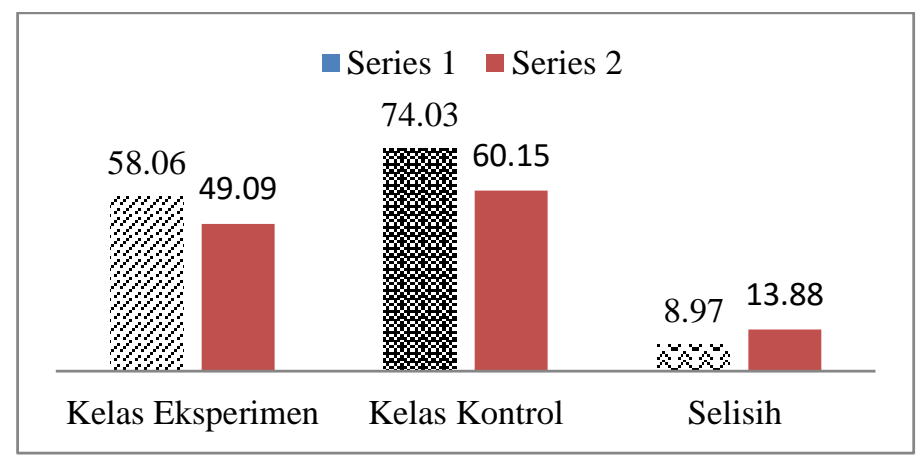

Gambar 2. Diagram perbandingan nilai rata-rata pretest dan posttestKelas eksperimen dan kelas kontrol

d. Peningkatan Hasil Belajar (N-Gain) Peserta Didik

Setelah diketahui nilai rata-rata prestest dan posttest pada kelas eksperimen dan kelas kontrol, maka selanjutnya menghitung peningkatan hasil belajar peserta didik dengan menggunakan rumus $\mathrm{N}$-Gain. Rumus $N$-Gain yang digunakan adalah sebagai berikut.

$$
\mathrm{G}=\frac{\text { skor posttest-skor pretest }}{\text { skormaksimal-skorpretest }}
$$

Hasil perhitungan $\mathrm{N}$-Gain nilai rata-rata pretest dan posttest antara kelas kontrol dan kelas eksperimen kemudian digolongkan dalam klasifikasi tinggi, sedang, dan rendah. Berikut tabel klasifikasi nilai $N$-Gain antara kelas eksperimen dan kelas kontrol.

Tabel 2. Klasifikasi Nilai $N$-Gain Kelas Eksperimen dan Kelas Kontrol

\begin{tabular}{cccccc}
\hline \multirow{2}{*}{ No } & Klasifikasi & \multicolumn{2}{c}{ Frekuensi } & \multicolumn{2}{c}{ Rata-rata -Gain } \\
\cline { 3 - 4 } & & $\begin{array}{c}\text { Kelas V A } \\
\text { (Eksperimen) }\end{array}$ & $\begin{array}{c}\text { Kelas V B } \\
\text { (Kontrol) }\end{array}$ & $\begin{array}{c}\text { Kelas V A } \\
\text { (Eksperimen) }\end{array}$ & $\begin{array}{c}\text { Kelas V B } \\
\text { (Kontrol) }\end{array}$ \\
\hline 1. & $>0,7$ (Tinggi) & 6 & 2 & & \multirow{2}{*}{0,42} \\
\cline { 1 - 4 } 2. & $0,3-0,7$ (Sedang) & 23 & 18 & 0,53 & \\
\cline { 1 - 4 } 3. & $<0,3$ (Rendah) & 2 & 8 & & \\
\hline
\end{tabular}

Berdasarkan tabel di atas, perbandingan nilai rata-rata $\mathrm{N}$-Gain untuk kelas eksperimen dan kelas kontrol. Kelas eksperimen nilai rata-rata $N$-Gain $(0,53)$ lebih tinggi dari kelas kontrol $(0,42)$. Nilai rata-rata yang dapat digambarkan dalam diagram berikut ini. Peserta didik kelas eksperimen yang tergolong dalam katagori "Tinggi" sebanyak 6 peserta didik, katagori "Sedang" sebanyak 23 peserta didik, dan katagori "Rendah" sebanyak 2 peserta didik, dengan rata-rata $N$-Gain sebesar 0,53. Adapun data $N$-Gain peserta didik kelas kontrol yang tergolong dalam katagori "Tinggi” sebanyak 2 peserta didik, katagori "Sedang" sebanyak 18 peserta didik, dan katagori "Rendah" sebanyak 8 peserta didik, dengan rata-rata $N$-Gain sebesar 0,42. Berikut diagram perbandingan rata-rata $N$-Gain pada kelas eksperimen dan kelas kontrol. 
Implementasi Pendekatan Science, Enviroment, Technology, and Society (SETS) terhadap Kemampuan Berpikir Kritis Peserta Didik Sekolah Dasar - Frida Destini, Dwi Yulianti, Lilik Sabdaningtyas, Alben Ambarita, Rochmiyati

DOI: https://doi.org/10.31004/basicedu.v6i1.1615

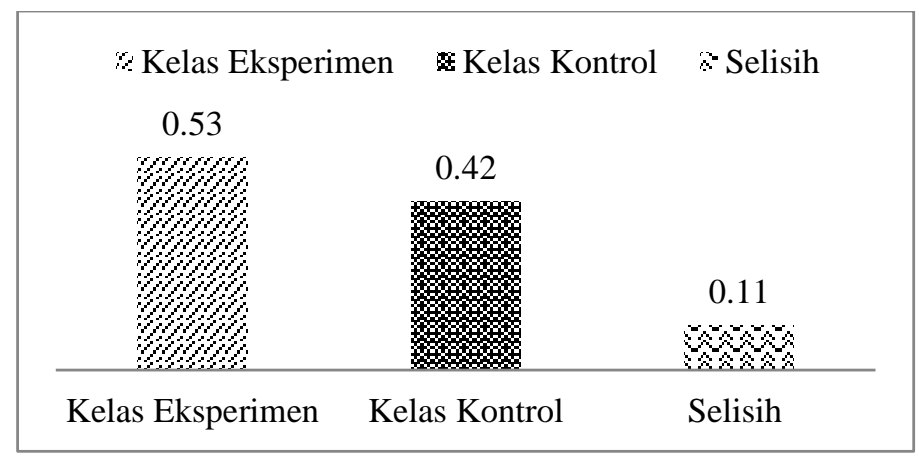

Gambar 2. Diagram batang rata-rata nilai $N$-Gain

Hal ini menunjukkan bahwa penerapan pendekatan Science, Environment, Technology, and Society (SETS) mampu melatih peserta didik untuk lebih mengembangkan kemampuan berpikir kritis dan lebih memahami materi karena didasarkan pada kegiatan pembelajaran yang dikaitkan pada kehidupan nyata dan lingkungan sekitar. Berpikir kritis adalah berpikir yang reflektif secara mendalam dalam pengambilan keputusan dan pemecahan masalah untuk menganalisis situasi, mengevaluasi argumen, dan menarik kesimpulan yang tepat, pendapat tersebut dikemukakkan oleh Stobaugh dalam (Azizah et al., 2018). Selain itu berpikir kritis adalah proses terorganisasi yang melibatkan proses mental yang menyangkut di dalamnya pemecahan masalah, pengambilan keputusan, menganalisis, dan inkuiri ilmiah hal itu diungkapkan oleh Ennis dalam (Maulidati et al., 2019). Menalar merupakan bagian dari kegiatan berpikir kritis. Pendapat tersebut juga sejalan dengan pernyataan (Ristiasari et al., 2012) yang menyatakan bahwa kemampuan berpikir kritis merupakan kompetensi yang harus dimiliki peserta didik.

Berdasarkan data analisis uji normalitas data pretest dan posttest kelas eksperimen dan kontrol menyatakan data berdistribusi normal. Hasil perhitungan uji normalitas secara manual pada data pretest kelas eksperimen diperoleh $\chi^{2}$ hitung $<\chi^{2}$ tabel yaitu 2,258 $<11,070$ hal tersebut menunjukkan bahwa data pretest kelas eksperimen berdistribusi normal. Perhitungan uji normalitas pada data posttest kelas eksperimen diperoleh $\chi^{2}$ hitung $<\chi^{2}$ tabel yaitu $6,657<11,070$ hal tersebut menunjukkan bahwa data posttest kelas eksperimen berdistribusi normal. Hasil perhitungan uji normalitas secara manual pada data pretest kelas kontrol diperoleh $\chi^{2}$ hitung $<\chi^{2}$ tabel yaitu 1,422 $<11,070$ hal ini menunjukkan bahwa data pretest kelas kontrol berdistribusi normal Perhitungan uji normalitas pada data posttest kelas kontrol diperoleh $\chi^{2}$ hitung $<\chi^{2}$ tabel yaitu 4,557 $<11,070$ hal ini menunjukkan bahwa data posttest kelas kontrol berdistribusi normal.

Uji homogenitas untuk pretest dan posttest kelas eksperimen dan kelas kontrol didapat bahwa data mempunyai variansi yang homogen. Selanjutnya, dilakukan uji hipotesis.Uji hipotesis menggunakan analisis regresi sederhana, kemudian diperoleh $\mathrm{F}_{\text {hitung }}>\mathrm{F}_{\text {tabel }}$ yaitu 34,12 > 4,18 maka Ha diterima dan Ho ditolak. Sehingga diperoleh kesimpulan bahwa terdapat pengaruh yang signifikan pada penerapan pendekatan Science, Environment, Technology, and Society (SETS) terhadap kemampuan berpikir kritis peserta didik.

Hasil uji hipotesis dengan menggunakan menggunakan uji independen sampel t-test untuk mengetahuiapakah ada perbedaan antara penerapan pendekatan Science, Environment, Technology, andSociety(SETS) dan pendekatan saintifik terhadap kemampuan berpikir kritis peserta didik diperoleh $\mathrm{t}_{\text {tabel }}$ dengan $\mathrm{dk}=(31+28-2)=57$ dengan taraf signifikansi $5 \%$, maka nilai $\mathrm{t}_{\text {tabel }}=2,000$, sehingga $\mathrm{t}_{\mathrm{hitung}}=1,170<$ $\mathrm{t}_{\text {tabel }}=2,000$. Hasil $\mathrm{t}_{\text {hitung }}$ kurang dari $\mathrm{t}_{\text {tabel }}$ artinya tidak terdapat perbedaan kemampuan berpikir kritis peserta didik sekolah dasar anatara kelas eksperimen dan kontrol. Hal ini menunjukan bahwa pendekatan Science, Environment, Technology, and Society(SETS) dan pendekatan saintifik sama-sama memiliki pengaruh dan peningkatan terhadap kemampuan berpikir kritis peserta didik, namun pada kelas eksperimen dengan 
Implementasi Pendekatan Science, Enviroment, Technology, and Society (SETS) terhadap Kemampuan Berpikir Kritis Peserta Didik Sekolah Dasar - Frida Destini, Dwi Yulianti, Lilik Sabdaningtyas, Alben Ambarita, Rochmiyati

DOI: https://doi.org/10.31004/basicedu.v6i1.1615

menggunakan pendekatan Science, Environment, Technology, and Society (SETS) mengalami peningkatan hasil belajar lebih tinggi dari kelas kontrol menggunakan pendekatan saintifik.

Hasil uji hipotesis tersebut sejalan dengan hasil penelitian (Rahma, 2012) yang menyatakan bahwa pendekatan SETS dapat menumbuhkan kemampuan berpikir kritis dan empati siswa terhadap lingkungan mencapai kriteria valid. Penelitian (Ragil \& Sukiswo, 2011) hasil analisis data menunjukkan adanya peningkatan hasil belajar kognitif, afektif, dan psikomotor dan dapat disimpulkan bahwa pendekatan SETS dapat meningkatkan kemampuan peserta didik. Selain itu, hasil penelitian ini juga selaras dengan penelitian yang dilakukan oleh (Yuniastuti, 2015) bahwa pendekatan SETS dapat membantu peserta didik untuk lebih meningkatkan kamampuan berpikir dan hasil belajarnya karena dalam pembelajaran SETS peserta didik mendalami dan mengalami sendiri pengetahuan yang idcarinya sehingga pengetahuan itu akan tetap diingat.

Terlepas dari hal tersebut, penelitian ini sudah dilaksanakan sesuai dengan prosedur yang ada. Namun, tentunya masih terdapat banyak kekurangan dalam penelitian ini. Hasil penelitian ini mungkin akan berbeda apabila dilaksanakan pada populasi dan sampel yang lebih besar.

\section{KESIMPULAN}

Berdasarkan hasil analisis data penelitian dan pembahasan dalam penelitian ini, maka dapat disimpulkan bahwa terdapat pengaruh pada penerapan pendekatan Science, Environment, Technology, andSociety (SETS) terhadap kemampuan berpikir kritis peserta didik sekolah dasar. Pengujian hipotesis yang menggunakan analisis regresi sederhana diperoleh $F_{\text {hitung }}>F_{\text {tabel }}$ yaitu 34,12 $>4,18$ berarti signifikan, artinya terdapat pengaruh yang signifikan pada penerapan pendekatan Science, Environment, Technology, andSociety (SETS) terhadap kemampuan berpikir kritis peserta didik.

\section{DAFTAR PUSTAKA}

Afriawan, M., Binadjab, A., \& Artikel, I. (2012). Pengaruh Penerapan Pendekatan Savi Bervisi Sets Pada Pencapaian Kompetensi Terkait Reaksi Redoks. Unnes Science Education Journal, 1(2). Https://Doi.Org/10.15294/Usej.V1i2.864

Amanda, S., Muharrami, L. K., Rosidi, I., \& Ahied, M. (2018). Peningkatan Kemampuan Berpikir Kritis Siswa Pada Pembelajaran Ipa Menggunakan Model Pembelajaran Berbasis Masalah Yang Berbasis Sets. Journal Of Natural Science Education Research, 1(1), 57-64. Https://Journal.Trunojoyo.Ac.Id/Nser/Article/View/4199

Azhar. (2013). Penggunaan Pendekatan Saintifik Dalam Pembelajaran Tematik Di Sekolah Dasar. Penggunaan Pendekatan Saintifik Dalam Pembelajaran Tematik Di Sekolah Dasar, 01(01), 1689-1699.

Azizah, M., Sulianto, J., \& Cintang, N. (2018). Analisis Keterampilan Berpikir Kritis Siswa Sekolah Dasar Pada Pembelajaran Matematika Kurikulum 2013. Jurnal Penelitian Pendidikan, 35(1), 61-70. Https://Doi.Org/10.15294/Jpp.V35i1.13529

Fakhriyah, F. (2014). Penerapan Problem Based Learning Dalam Upaya Mengembangkan Kemampuan Berpikir Kritis Mahasiswa. Jurnal Pendidikan Ipa Indonesia, 3(1), 95-101. Https://Doi.Org/10.15294/Jpii.V3i1.2906

Isti Nur Hayanah, S. (2014). Peningkatan Kualitas Pembelajaran Ipa Melalui Pendekatan Sets Pada Kelas V. Joyful Learning Journal, 2(2). Https://Doi.Org/10.15294/Jlj.V2i3.2092

Khasanah, N. (2015). Sets (Science, Environmental, Technology And Society) Sebagai Pendekatan Pembelajaran Ipa Modern Pada Kurikulum 2013. Prosiding Kpsda, 1(1).

Kusmianty, D., Widiyanto, B., \& Kusuma, M. (2020). Efektivitas Model Pembelajaran Sets Metode 
Implementasi Pendekatan Science, Enviroment, Technology, and Society (SETS) terhadap Kemampuan Berpikir Kritis Peserta Didik Sekolah Dasar - Frida Destini, Dwi Yulianti, Lilik Sabdaningtyas, Alben Ambarita, Rochmiyati

DOI: https://doi.org/10.31004/basicedu.v6i1.1615

Praktikum Pada Materi Pemanasan Global Dalam Meningkatkan Kemampuan Berpikir Kritis. Cakrawala: Jurnal Pendidikan, 41-51.

Kusumah, R. G. T. (2019). Peningkatan Kemampuan Berfikir Kritis Mahasiswa Tadris Ipa Melalui Pendekatan Saintifik Pada Mata Kuliah Ipa Terpadu. Ijis Edu : Indonesian Journal Of Integrated Science Education, 1(1), 71. Https://Doi.Org/10.29300/Ijisedu.V1i1.1762

Machin, A. (2014). Implementasi Pendekatan Saintifik, Penanaman Karakter Dan Konservasi Pada Pembelajaran Materi Pertumbuhan. Jurnal Pendidikan Ipa Indonesia, 3(1), 28-35. Https://Doi.Org/10.15294/Jpii.V3i1.2898

Maulidati, I. S., Dantes, N., \& Tika, N. (2019). Pengaruh Pembelajaran Berpendekatan Saintifik Berorientasi Science Environment Technology Society Terhadap Kemampuan Berpikir Kritis Dan Hasil Belajar Ipa Siswa Kelas V. Pendasi: Jurnal Pendidikan Dasar Indonesia, 2(2), 59-71. Https://Doi.Org/10.23887/Jpdi.V2i2.2693

Pratiwi, F. A. (2014). Pengaruh Penggunaan Model Discovery Fitri Apriani Pratiwi Nim F02110003. Pengaruh Penggunaan Model Discovery Learning Dengan Pendekatan Saintifik Terhadap Keterampilan Berpikir Kritis Siswa Sma, 6, 10.

Ragil, Z., \& Sukiswo, S. E. (2011). Penerapan Pembelajaran Sains Dengan Pendekatan Sets Pada Materi Cahaya Untuk Meningkatkan Hasil Belajar Siswa Kelas V Sd. Jurnal Pendidikan Fisika Indonesia, 7(1).

Rahma, A. N. (2012). Pengembangan Perangkat Pembelajaran Model Inkuiri Berpendekatan Sets Materi Kelarutan Dan Hasilkali Kelarutan Untuk Menumbuhkan Keterampilan Berpikir Kritis Dan Empati Siswa Terhadap Lingkungan. Journal Of Research And Educational Research Evaluation, 1(2).

Retno, R. S., \& Marlina, D. (2018). Implementasi Sets (Science Environment Technology And Society) Pada Pembelajaran Ipa Sd Berbasis Inquiry Terhadap Berpikir Ilmiah Siswa Kelas 4 Mi Al-Irsyad Madiun. Bio-Pedagogi, 7(2), 54. Https://Doi.Org/10.20961/Bio-Pedagogi.V7i2.27618

Rini, C. P. (2017). Pengaruh Pendekatan Sets (Science, Environment, Technology And Society) Terhadap Keterampilan Proses Sains Siswa Sekolah Dasar. Pendas : Jurnal Ilmiah Pendidikan Dasar, 2(1), 56. Https://Doi.Org/10.23969/Jp.V2i1.450

Ristiasari, T., Priyono, B., Sukaesih, S., \& Biologi, J. (2012). Unnes Journal Of Biology Education Model Pembelajaran Problem Solving Dengan Mind Mapping Terhadap Kemampuan Berpikir Kritis Siswa Info Artikel. J.Biol.Educ, 1(3), 50229. Http://Journal.Unnes.Ac.Id/Sju/Index.Php/Ujeb

Vieira, R. M., \& Tenreiro-Vieira, C. (2016). Fostering Scientific Literacy And Critical Thinking In Elementary Science Education. International Journal Of Science And Mathematics Education, 14(4), $659-680$.

Wijaya, W. S., Feronika, T., \& Fairusi, D. (2018). Penerapan Problem Based Learning Berpendekatan Sets Terhadap Keterampilan Berpikir Kritis Siswa. Jtk (Jurnal Tadris Kimiya), 3(1), 94-103. Https://Doi.Org/10.15575/Jtk.V3i1.2338

Yuniastuti, E. (2015). Pengaruh Model Pembelajaran Sets (Science, Environment, Technology And Society) Terhadap Hasil Belajar Biologi Siswa Kelas Vii Smp Kartika V-1 Balikpapan Tahun Pelajaran 2015/2016. Jst (Jurnal Sains Terapan), 1(2), 72-78. Https://Doi.Org/10.32487/Jst.V1i2.94 